PRACE GEOGRAFICZNE

zeszyt 162, 2020, 69-87

doi: 10.4467/20833113PG.20.013.13100

Instytut Geografii i Gospodarki Przestrzennej UJ

Komisja Geograficzna, Polska Akademia Umiejętności

Wydawnictwo Uniwersytetu Jagiellońskiego

\title{
ZRÓWNOWAŻONY I INNOWAGYJNY KAMPUS UNIWERSYTECKI NA PRZYKŁADZIE KAMPUSU SZKOŁY GŁÓWNEJ HANDLOWEJ W WARSZAWIE
}

Marek Bryx

\section{Sustainable and innovative university campus: a case study of the Warsaw School of Economics campus}

Abstract: Sustainable development is a concept that is already established in our consciousness. It can be assumed that, in relation to the city, it means the implementation of 4 principles (goals) that such a city and its inhabitants should strive to achieve (Szelagowska, Bryx 2015), namely: 1 . Aspire to be close to the ecosystem, obtaining spatial order with the least possible interference in this ecosystem. 2. Produce no more waste than the city can assimilate, while consuming no more resources than it can recreate. 3. To promote and consolidate a lifestyle consistent with the above principles, which all residents create by their daily conduct, not just the city authorities. 4. Comply with the principles of honesty and justice. This definition, a little too detailed, aims to highlight two aspects of sustainable development: human proximity to the environment and ethics in human behaviour towards the natural and social environment. The university campus is part of the city, intellectually radiating, forging and disseminating new concepts. By disseminating the idea of a sustainable city, the campus should be an example of implementing these principles in a community constituting an urban enclave. Answering the questions: is this happening? and is it possible at universities that were created before the emergence of the idea of sustainable development? is the purpose of this article. The author, considering these issues, uses the experience of the campus of the Warsaw School of Economics, designed 100 years ago, constructed in stages and seeking its path of development.

Keywords: sustainable university campus, innovative university, campus regeneration, Warsaw School of Economics 
Zarys treści: Zrównoważony rozwój to pojęcie, które utrwaliło się już w naszej świadomości Można przyjąć, że w odniesieniu do miasta oznacza ono realizację 4 zasad (celów), do których osiągnięcia takie miasto, jego mieszkańcy powinni dążyć (Szelągowska, Bryx 2015), a mianowicie: 1. Aspirować do tego, aby być blisko ekosystemu, uzyskując tad przestrzenny miasto jest w stanie zasymilować, a równocześnie konsumować nie więcej zasobów, niż jes w stanie odtworzyć. 3. Propagować i utrwalać styl życia zgodny z powyższymi zasadami, któr tworzą wszyscy mieszkańcy swoim codziennym postępowaniem, a nie tylko władze miasta. 4. Przestrzegać zasad uczciwości i sprawiedliwości. Ta definicja, trochę zbyt szczegółowa, w gruncie rzeczy zmierza do podkreślenia dwóch aspektów zrównoważonego rozwoju: bliskośc człowieka ze środowiskiem naturalny izasad etyki w postẹpowaniu ludzi wobec środowiska naturalnego i społeczneogo. Kampus uniwersytecki jest czéścią miasta, promieniującą intelektualnie, wykuwającą i upowszechniającą nowe koncepcje. Rozpowszechniając ideę zrównoważonego miasta, kampus powinien być przykładem wdrożenia tych zasad w społeczności będące enklawą miejską. Odpowiedź na pytania, czy tak się dzieje i czy jest to możliwe na uczelniach, które powstały przed pojawieniem się idei zrównoważonego rozwoju, stanowi cel tego artykułu. Autor, rozważając te kwestie, wykorzystuje dó́wiadczenia kampusu Szkoły Głównej Handlowej w Warszawie, zaprojektowanego 100 lat temu, realizowanego etapami i poszukującego swojej drogi rozwoju.

Stowa kluczowe: zrównoważony kampus uniwersytecki, innowacyjny uniwersytet, przebudowa kampusu, Szkoła Główna Handlowa w Warszawie

\section{Zarys historii Uczelni i wyjątkowość jej historycznego kampusu}

Szkoła Główna Handlowa w Warszawie wywodzi swój początek od Kursów handlowych męskich, zainaugurowanych w Warszawie w 1906 r. przez Augusta Zielińskiego, przekształconych później w Wyższą Szkołę Handlową. Ustawą Sejmu RP z 13 lutego 1924 r. przyznano WSH prawa państwowych szkół akademickich jako dziesiątej uczelni w kraju (Gawerski 2007). Aż do roku 1949 uczelnia była podmiotem prywatnym, który utrzymywał się głównie z czesnego oraz opłat za certyfikowanie różnych produktów.

Rektor, Bolesław Miklaszewski, dążył do upowszechnienia „wśród szerokich mas społecznych ekonomicznych metod myślenia” (Miklaszewski 2007), dlatego rozwój uczelni, w tym budowę kampusu, uważał za sprawę priorytetową. Senat nie popierał jego idei przeniesienia uczelni ze Śródmieścia na dalekie wówczas przedmieścia stolicy. Ostatecznie w podjęciu pozytywnej decyzji pomogła budowa linii tramwajowej wzdłuż ul. Rakowieckiej.

W 1923 r. ogłoszono konkurs na projekt kampusu uczelni. Wygrał go Jan Witkiewicz-Koszczyc. Jednak przedstawiony przez niego szkic (fot. 1) nigdy nie został zrealizowany, głównie z powodu kosztów, jakie niosło ze sobą tak duże przedsięwzięcie. Dwa lata później władze uczelni zaakceptowały projekt budynku wolnostojącego dla 1600

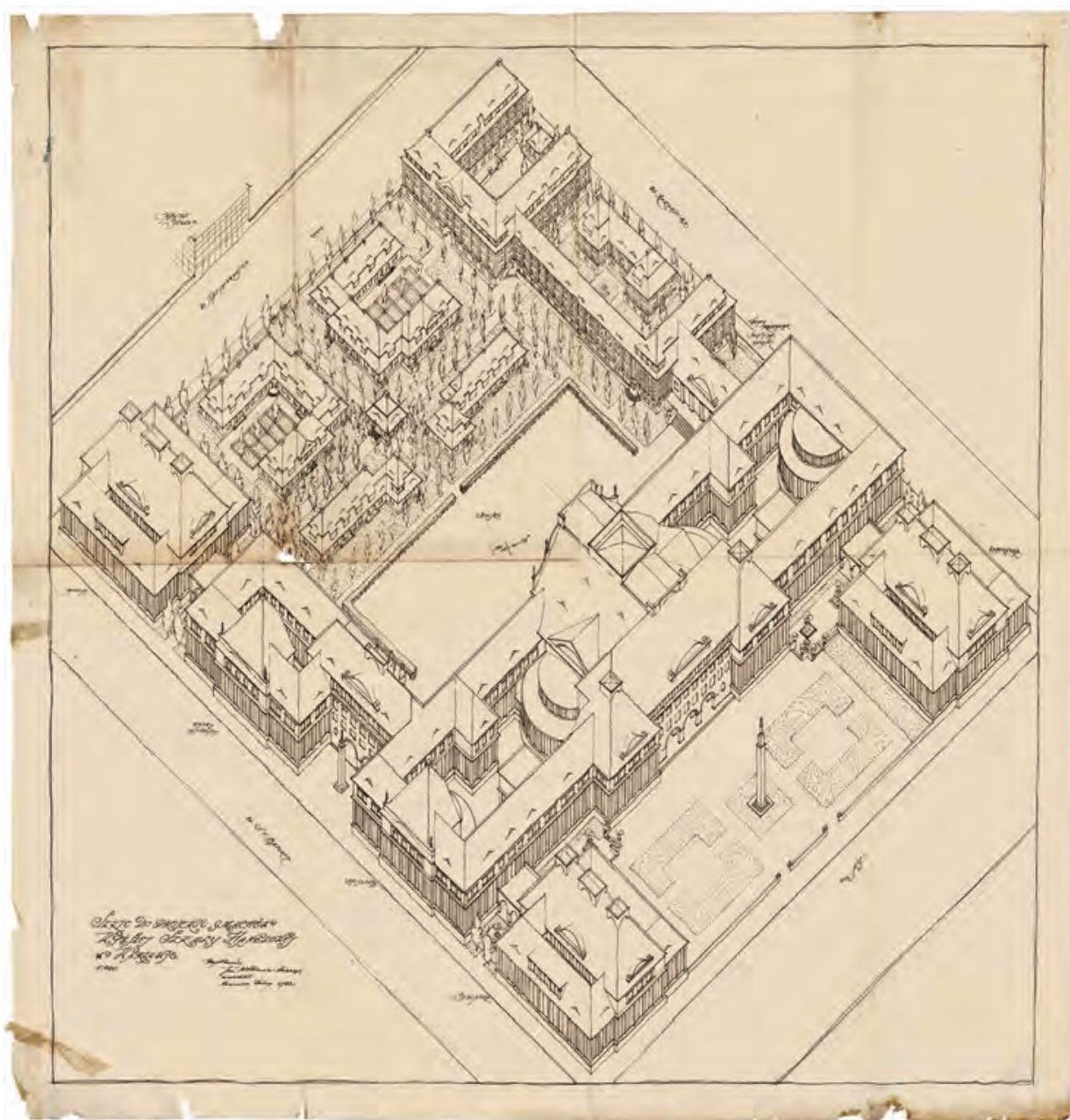

Fot. 1. Pierwszy szkic budynku WSH Jana Witkiewicza-Koszczyca Photo 1. First sketch of the WSH; building of by Jan Witkiewicz-Koszczyc Źródto: Archiwum SGH; przekazane przez Muzeum Architektury we Wrocławiu. Source: SGH Archives; received from the Museum of Architecture in Wrocław.

studentów, który mógłby być włączony w przyszłości w kompleks kampusu (fot. 2). Nazwano go „pawilonem zakładów doświadczalnych” (dziś - budynek A), gdyż sale otaczające główną aulę wykładową wyposażone były w media umożliwiające certyfikowanie wyrobów przez studentów na zajęciach. 


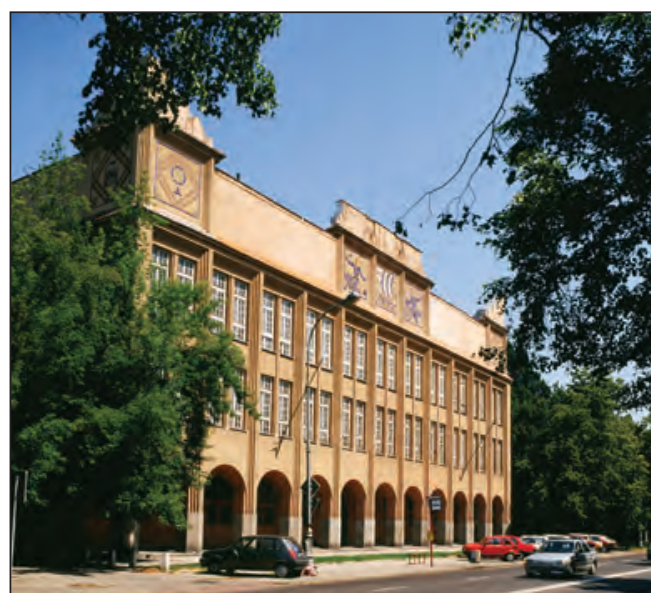

Fot. 2. Ściana frontowa budynku A, lata 70 Photo 2. Front wall of building A, 1970s

Źródto: M. Górski, Archiwum SGH. Source: M. Górski, SGH Archives.

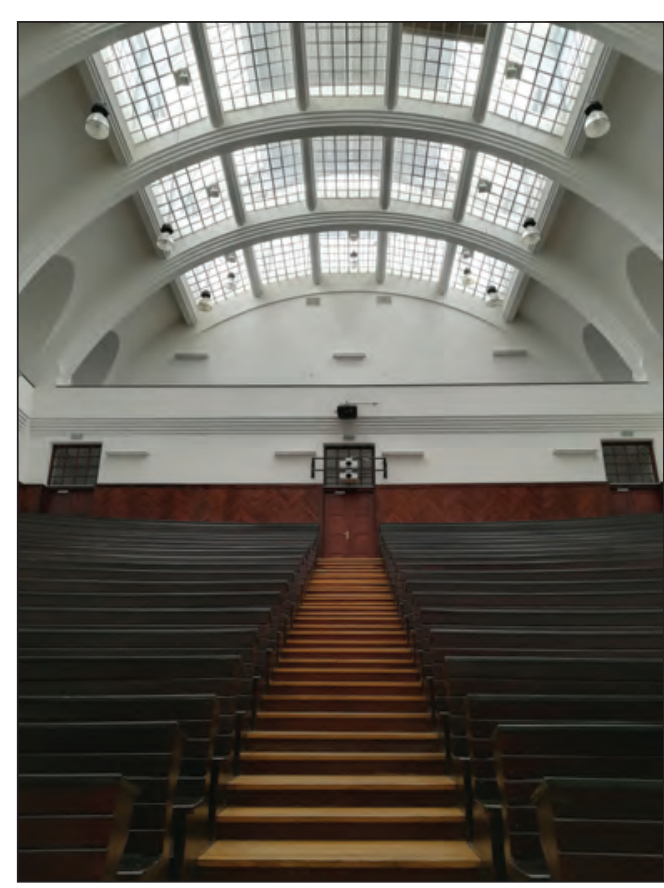

Obiekt wykonano w nowej wówzas technologii żelbetowej w ciągu 12 miesięcy. Słupy konstrukcyjne, znajdując się w osi co $4 \mathrm{~m}$, tworzą siatke nośna budynku, a ściany wypełniono cegłą kratówką.

$\mathrm{Na}$ wprost wejścia do budynku znajduje się szatnia, a korytarz w kształcie litery U otacza atrium, czyli aulę („A”) na ok. 600 osób, przeszklona na całej długości oryginalną latarnią (fot. 3). Po zewnętrznej stronie korytarza, na 3 kondygnacjach zlokalizowano sale do pracy w grupach i pomieszczenia administracyjne. Posiadały one wysokie okna, których najwyższa część była uchylna, umożliwiając dopływ świeżego powietrza w trakcie zajęć, także zimą. Innowację tę zlikwidowano w latach 70., instalując nowe plastikowe okna.

W roku 1927, rok po oddaniu pierwszego budynku, rozpoczęto prace nad budynkiem biblioteki, która potwierdzałaby status uczeln akademickiej. Obiekt, identyczny kubaturowo z budynkiem A, zosta lustrzanie odwzorowany na północ od osi symetrii, która do dziś jest osią wschód-zachód kampusu (fot. 4).

Wejście główne do bibliotek znajduje się od strony planowane

Fot. 3. Aula A w budynku A (fot. M. Bryx)

Photo 3. Auditorium A in building A (photo by M. Bryx) ul. Batorego, którą jednak po wojnie utworzono bardziej na północ, przez co ukryto przed mieszkańcami miasta jeden $z$ najpiękniejszych budynków w mieście, niezniszczonych nawet w trakcie wojny (fot. 5 ).

Budowa drugiej w Europie, po Zurychu, publicznej bibliotek trwała 3 lata. Uroczyste otwarcie z udziałem Prezydenta RP odbyło się w 1930 r. Przyczyną wydłużonego cyklu inwestycyjnego był brak środków finansowych, pomimo zaproszenia jako partnera Biblioteki Narodowej, która wniosła $1 / 3$ środków koniecznych do sfinalizowania inwestycji i przez wiele lat użytkowała budynek bibliotek wspólnie z SGH.

W budynku, który przetrwa w nienaruszonym stanie od 1930 r. na wprost wejścia znajduje się szatnia, dzięki specjalnym świetlikom doświetlona światłem dziennym. Schody "prowadzą do wiedzy", czyli do czytelni głównej o kubaturze prawie $1000 \mathrm{~m}^{3}$, doświetlone 4 stron świata oraz przez rozety w suficie (fot. 6). Magazyn książek zlokalizowano pod czytelnią i połązono windami dostarczającymi książki. Ogromne okna przeszklone

Fot. 5. Budynki kampusu i ich otoczenie

Photo 5. Campus buildings and their surroundings

Zródto: M. Ostrowski, Archiwum SGH. Source: M. Ostrowski, SGH Archives.

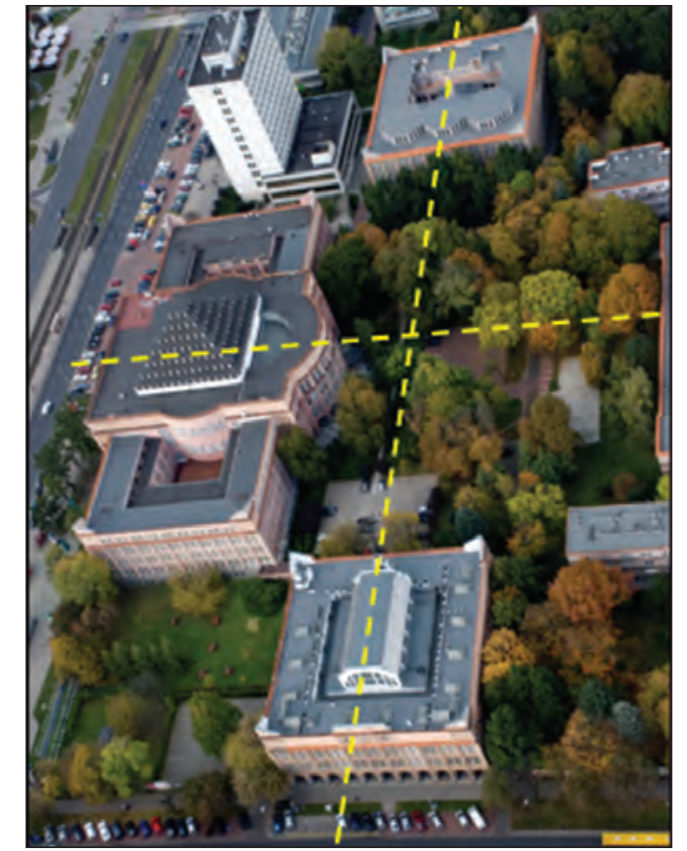

Fot. 4. Osie symetrii kampusu

Photo 4 . Campus symmetry axes

Źródto: M. Ostrowski, Archiwum SGH.

Source: M. Ostrowski, SGH Archives.

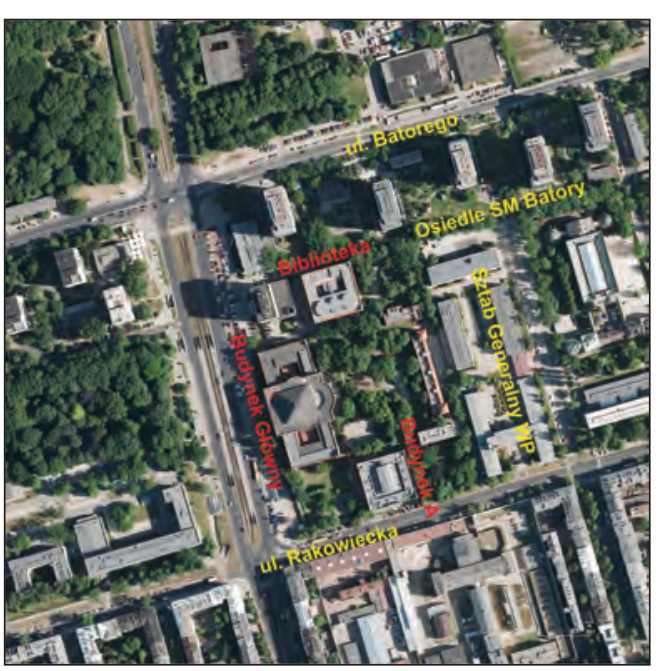




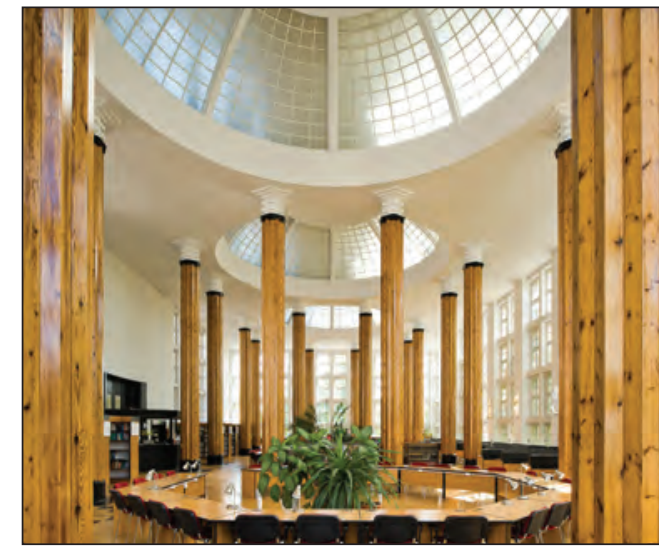

Fot. 6. Czytelnia główna w budynku biblioteki SGH

Photo 6. Main reading room in the SGH library building

Źródto: M. Górski, Archiwum SGH

Source: M. Górski, SGH Archives.

były zielonkawymi szybami zapobiegającymi żółknięciu papieru.

Budynek biblioteki zawiera wiele interesujących detali, np. oryginalne lampy z lat 30., mozaiki z cegły klinkierowej, w tym sowę symbol mądrości - i orła w koronie.

Przed wojną wybudowano jeszcze nieduży budynek z mieszkaniami dla profesorów, który stanowi północną część kompleksu mieszkalnego dla studentów i pracowników, zrealizowanego już po upaństwowieniu uczelni.

W 1949 r. do SGH przyłączono Szkołę Główną Służby Zagranicznej, upaństwowiono ją, zmieniono nazwę na Szkoła Główna Planowania i Statystyki i utworzono 4 wydziały: Ekonomiki Produkcji, Handlu Wewnętrznego, Handlu Zagranicznego, Finansów i Statystyki, do których w 1968 r. dołączył Wydział Ekonomiczno-Społeczny. Równocześnie podjęto prace projektowe nad budynkiem głównym. Zgodnie z pierwotną koncepcją z 1923 r. miał on połączyć budynek A i bibliotekę w jeden kompleks. Mimo sprzeciwu J. Witkiewicza-Koszczyca budynek skrócono o ok. $60 \mathrm{~m}$ i zrealizowano jako wolnostojący (fot. 7).

Udało się jednak zachować jego układ ze specyficznym hallem, tzw. aulą spadochronową, (fot. 8) o niepowtarzalnym, piramidalnym kształcie dachu, otoczonym 9 tradycyjnymi aulami o zróżnicowanej liczbie miejsc dla studentów (od 200 do 800). W piwnicach budynku zlokalizowano czwartą w Warszawie pływalnię.

$Z$ pierwotnego zamysłu architektonicznego udało się ostatecznie zbudować wszystkie budynki otaczające dość duży ogród/park, którego przestrzenie miały służyć do swobodnych spotkań i wymiany poglądów kadry nauczającej ze studentami w luźniejszej, nieformalnej atmosferze. Podobnie integrującymi społecznośc miejscami były stołówka, bufet, palarnia, klub profesorski, a także szerokie, doświetlone korytarze.

Oceniając kampus SGH (uczelnia wróciła do przedwojennej nazwy w 1991 r.) z dzisiejszej perspektywy, można stwierdzić, że pomimo iż nie został zrealizowany zgodnie z pierwotnym zamysłem, to jednak jest perłą warszawskiej międzywojenne architektury, co potwierdzały przedwojenne przewodniki po Warszawie, zalecające

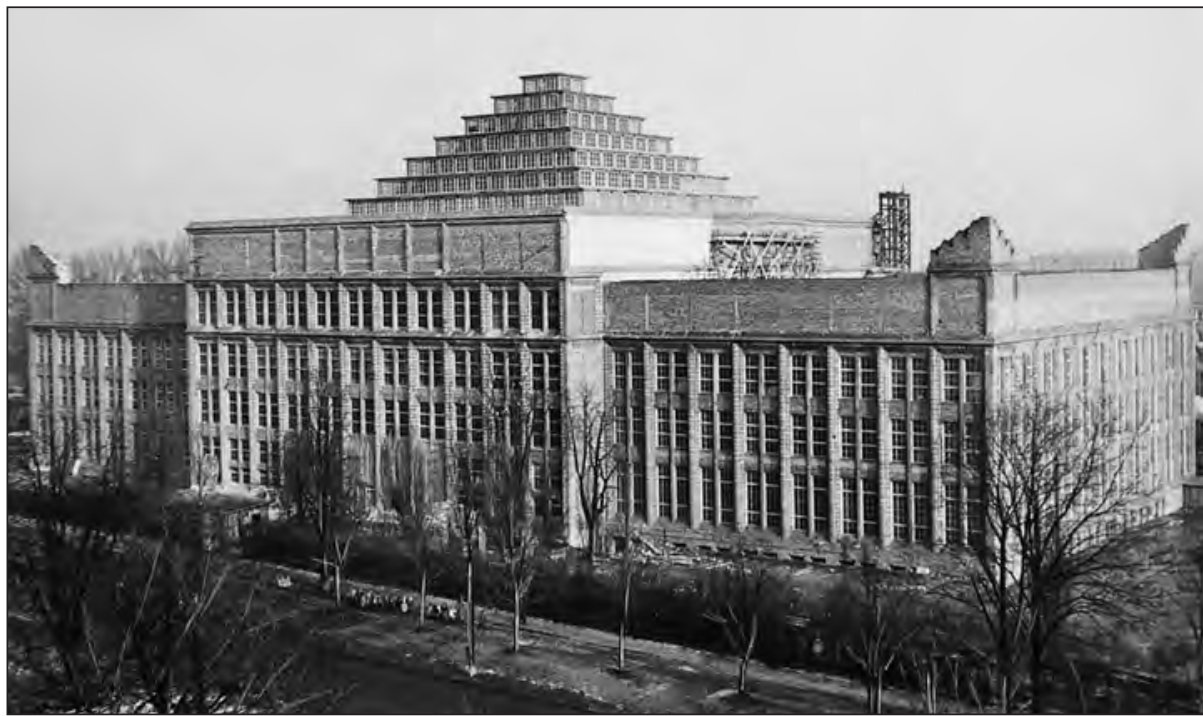

Fot. 7. Budynek główny SGPiS (SGH) w budowie

Photo 7. Main building of the SGPiS (SGH) under construction Źródto: Archiwum SGH

Source: SGH Archives.

Fot. 8. Dach auli spadochronowej w budynku głównym SGH Photo 8. Ceiling of the parachute hall in the main building of the Warsaw School of Economics

Źródto: M. Górski, Archiwum SGH. Source: M. Górski, SGH Archives.

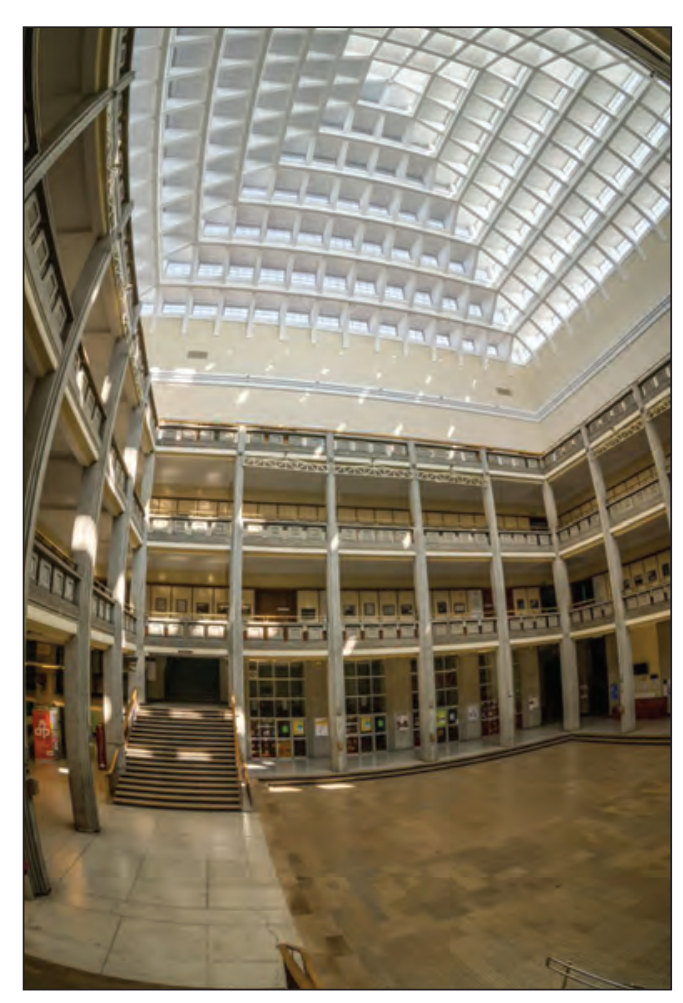


obejrzenie obydwu oryginalnych budynków (Leśniakowska 1998). Nie powsta jednak plac przed budynkiem głównym, kolejne planowane miejsce integracji i budowania relacji międzyludzkich. Mimo to unikatowość kampusu SGH tkw w jego założeniu urbanistycznym i oryginalnej architekturze. Jan Witkiewicz-Koszczyc został uznany przez potomnych za ,architekta światła”, bo zaprojektowane budynki budzą podziw nowatorskimi rozwiązaniami i obfitym, oryginalnym doświetleniem pomieszczeń ('Trzcińska 2015).

Po śmierci architekta zaadaptowano strychy i wybito okna w attyce budynku głównego, przez co zepsuto ponownie proporcje budynków ${ }^{1}$. W ramach dokonywanych remontów pozbyto się także drewnianych okien, zastępując je tańszymi plastikowymi. Zlikwidowano przy okazji lufciki pozwalające wietrzyć sale w trakcie zajęć. Takie właśnie detale, jak możliwość swobodnego przepływu powietrza a także ruchome półki w magazynie biblioteki, windy dostarczające książki z magazynu do czytelni, a nawet katalogi biblioteczne zaprojektowane przez architekta decydowały także o nowatorstwie kampusu (Witkiewicz-Koszczyc 1933).

W latach 1978-1984 w północno-zachodnim narożniku kampusu zbudowano w doświadczalnej technologii tzw. budynek F, który został wyłączony z eksploatacj w 2010 r., a rozebrany w 2016 r., odsłaniając widok na zachodnią ścianę biblioteki, pokrytą także częściowo mozaikami (fot. 9).

\section{Wyzwania wynikające z nowych technologii, trendów w nauczaniu}

W założonej przez Platona około roku 387 p.n.e. Akademii, która przetrwała aż do 529 r. naszej ery, za podstawową metodę nauczania uważano rozmowę nauczyciela z uczniem - dysputę. Według Platona, nauczyciel za pomocą planowo ułożonych pytań powinien ucznia skłaniać do czynienia spostrzeżeń, porównań, ostrożnych uogólnień, ścisłych określeń i wniosków. Tę właśnie metodę stosowała przez ponad 900 lat Platońska Akademia (Dembiński 2010). I choć również tam stosowano wykłady (trudniejsze przed południem!), to dopiero w wiekach późniejszych upowszechniono je jako metodę przekazującą wiedzę. Jej zaletą jest jasne, chronologiczne przedstawianie faktów i przekazywanie wniosków. Wadą zaś to, że uwalnia słuchacza od myślenia, pozbawia go twórczych wątpliwości, które są podstawą nowych odkryć.

Wiek XXI przyniósł masowy rozwój nowych technologii, a przez to udostępnienie nieprzebranych zasobów informacji. Wydawało się, że przerwie to ów dialog profesora ze studentem. Tymczasem młodzi ludzie, aczkolwiek na ogół sprawniejsi

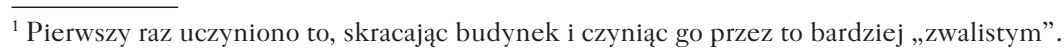

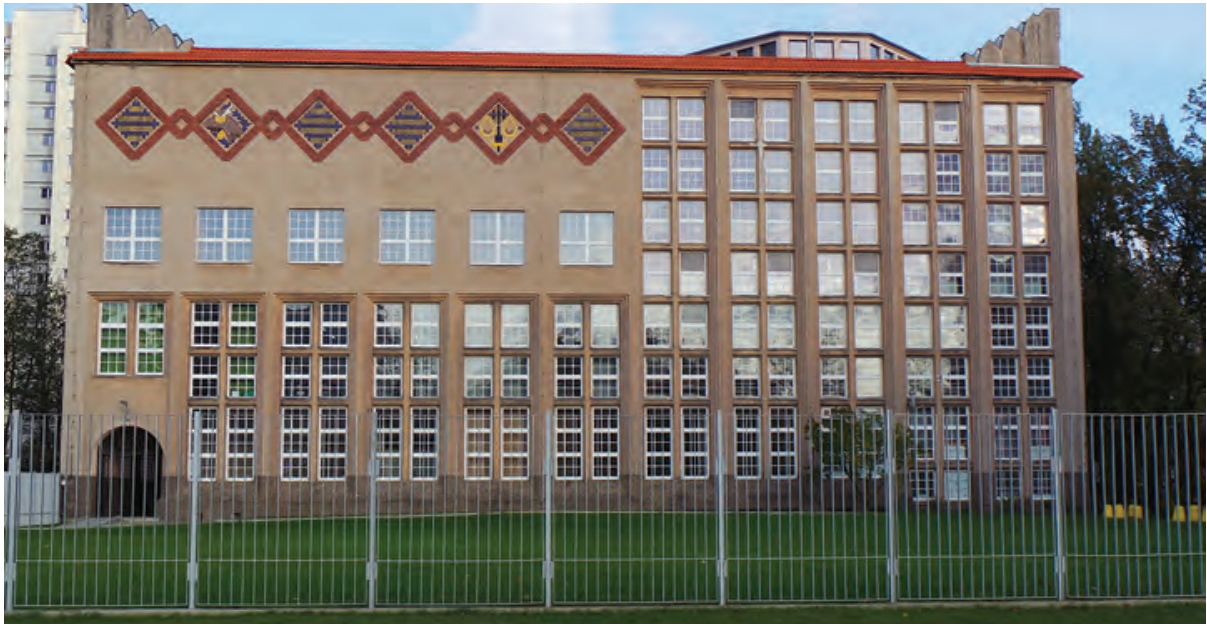

Fot. 9. Zachodnia ściana biblioteki SGH (fot. M. Bryx)

Photo 9. Western wall of the Warsaw School of Economics (photo by M. Bryx)

w wykorzystywaniu nowych technologii niż ich profesorowie, nie zadowalają się wiedzą powierzchowną, niezweryfikowaną. Co więcej, niedostatek wykształcenia często utrudnia im zrozumienie i przyswojenie wiedzy. Nadal więc odczuwają potrzebę rozmowy, dyskusji z nauczycielem.

W rezultacie, pomimo stosowania nauczania na odległość, do początku 2020 r. była to metoda wspomagająca nauczanie, gdyż około $15 \%$ wykładów przygotowywano jako e-learningowe. Dopiero pandemia w 2020 r. wymusiła całkowite przekazywanie wiedzy, a także egzaminowanie czy organizowanie spotkań studenckich kół naukowych w trybie online. Rozmowy ze studentami dowodzą jednak, że heurystyka w nauczaniu jest jeszcze bardziej potrzebna, niż była do tej pory, a kontakty twarzą w twarz są trwałym elementem współpracy, nie tylko na poziomie akademickim. Interpretacja zjawisk staje się czymś, czego student - atakowany w sieci różnymi, także sprzecznymi informacjami - najczęściej nie jest w stanie dokonać sam. Skłaniało to już w przeszłości studentów do wyrażania poglądu, iż potrzebna jest przestrzeń do spotkań półformalnych, w swobodnie kształtowanych grupach, czyli miejsca, w których grupa może się odizolować i (korzystając także z najnowszej techniki) podjąć wspólną pracę (Górski 2011).

Do 2020 r. dominował pogląd, że technika nie wyprze z kampusu ani studenta, ani tym bardziej profesora, aczkolwiek zmieni częściowo sposób ich życia i pracy w przestrzeni tego obiektu. Znaczenie różnorodności, elastyczności i dostępności tej przestrzeni wyraźnie rosło. Podczas gdy dostęp do Internetu w każdym punkcie 
kampusu stał się czymś oczywistym, to dostęp do właściwej przestrzeni ciągle jest pożądany. Z okazjonalnych rozmów ze studentami wynika, że COVID-19 dotychczas tego nie zmienił. Jeśli jednak wprowadzone ograniczenia przetrwają kilka roczników studentów, to kto wie, czy sytuacja nie ulegnie zmianie.

\section{Przestrzenie kampusu - pierwsza zasada zrównoważonego rozwoju}

W 2011 r. na konferencji INTA w Tallinie dokonano podziału przestrzeni uniwersyteckich na wewnętrzne i zewnętrzne, a także na te o ograniczonym dostępie dla osób spoza społeczności akademickiej i otwarte dla wszystkich (Bryx 2011).

W obu przestrzeniach wyraźnie dominuje potrzeba zwiększenia elastyczności, funkcjonalności i łączenia ich z ekosystemem. Zieleń jest obecna na terenie wszystkich kampusów, nawet najbardziej kompaktowych, jak choćby w przerobionym z budynków klasztornych kampusie JADS. W zasadzie wszystkie sześć europejskich uczelni badanych przez zespół SGH w 2017 r., czyli: ALTO Helsinki, JADS s'Hertogenbosh, Uniwersytet Technologiczny Eindhoven, Uniwersytet Technologiczny Berlin, DIT, Uniwersytet Korwina Budapeszt (Bryx 2017) nie tylko uelastyczniły przestrzenie wewnętrzne, ale też wzbogaciły je o nowe funkcje, starając się także wprowadzić do nich jak najwięcej roślin.

Mimo to wciąż podejmowane są nowe działania na rzecz zwiększenia ekosystemu na terenie kampusu i jego dostępności; pojawia się coraz więcej roślin - drzew, krzewów, kwiatów - a także wody w postaci sadzawek, fontann, strumyków zarówno w przestrzeniach zewnętrznych, jak i wewnątrz budynków. Bliskie obcowanie z naturą zapewniają ławki i stoły, zlokalizowane w uroczych zakątkach, a także szerokie schody wiodące w stronę enklaw zieleni i wody, dających poczucie wspólnoty z przyrodą i możliwość umysłowego odpoczynku.

Próby uelastycznienia każdej z przestrzeni są także szeroko widoczne. Nauka nie jest jednofunkcyjna. Przyswajamy wiedze przez dyskurs, namysł; słuchając, rozważając, polemizując. Przestrzeń ma w tym pomagać, stąd dążenie do zwiększenia możliwości jej wykorzystania, głównie dzięki jej aranżacji i wprowadzanym do niej meblom. Zamieniając tradycyjne ławki na krzesła umożliwiające swobodną i natychmiastową aranżację jednego lub kilku zespołów studenckich (fot. 10), uzyskujemy elastyczność odpowiadającą potrzebom chwili.

Podobnie w miejscach pracy, wykorzystywanych na zmianę przez wiele osób, wprowadza się podwyższane stoły, biurka czy krzesła, umożliwiające swobodne korzystanie z nich przez każdego. Dobrym przykładem są także przestrzenie korytarzy, które kiedyś umożliwiały wyłącznie przemieszczanie się, a dziśs stają się miejscem spotkań, dyskusji czy relaksu. Umieszczenie na wąskich, akustycznych korytarzach niby- -budek telefonicznych, służących do wygłuszania rozmów, także ten komfort wzmacnia (fot. 11a i 11 b) Zatem jednofunkcyjne przestrzenie w starych murach mogą stać się, dzięki przemyślanym zabiegom, przestrzeniami wielofunkcyjnymi ekologicznymi.

Przestrzenie otwarte szczególnie umożliwiają rozbudowywanie więzi z naturą. Można postrzegać je dwojako:

A) Jako przestrzenie kampusu udostępniane bez ograniczeń osobom niebędącym członkami społeczności akademickiej. W SGH będzie to ogród wewnętrzny, jak również budynek biblioteki.

B) Jako leżące blisko granic kampusu - zarówno publiczne, jak i prywatne, gdzie studenci i profesorowie spotykają się przypadkiem lub celowo z osobami z zewnątrzumożliwiające nawiązanie oraz utrwalanie takich relacji.

We wszystkich rodzajach przestrzeni widać dążenie do zapewnienia ładu i podkreślania więzi z naturą. Uzyskany przez to komfort użytkowników ma wzmocnić odkrywczość, kreatywność, innowacyjność przede wszystkim członków społecznośc
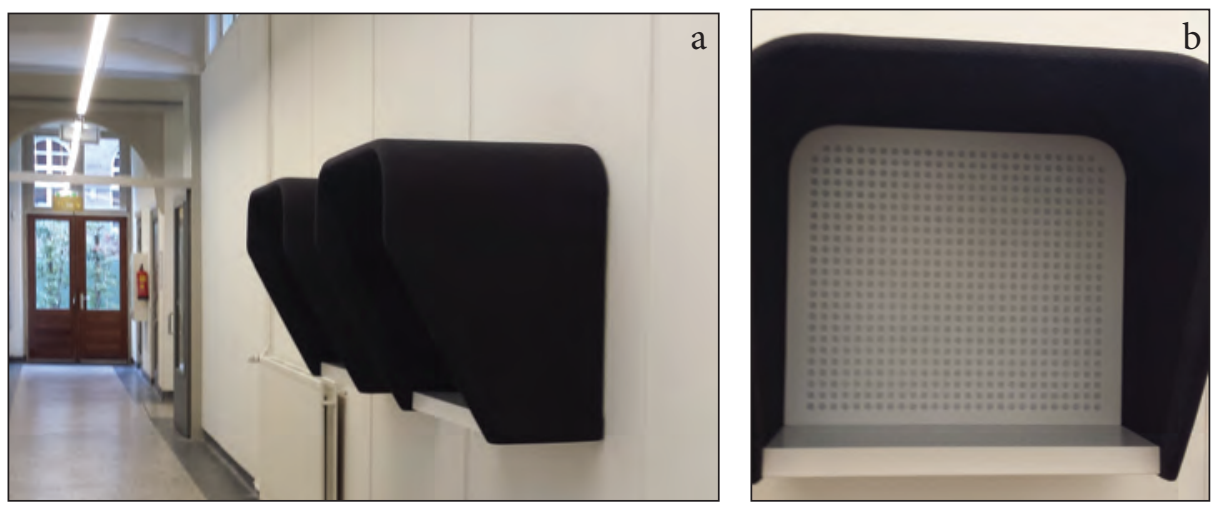

Fot. 11. Wygłuszacze rozmów telefonicznych w JADS (fot. M. Bryx) Photo 11. Sounds absorbers on the JADS campus (photo by M. Bryx) 
akademickiej. Jeśli zaś to zadanie można skuteczniej realizować poprzez kontak z innymi osobami, to przestrzeń ma takie spotkania ułatwiać. Kreatywność grupy objawia się najbardziej wówczas, kiedy w odpowiednich warunkach spotykają się osoby o podobnych zainteresowaniach, ale z różnym rodzajem wiedzy. Można więc zgodzić się ze stwierdzeniem, że miarą sukcesu kampusu stała się przestrzeń, a ściślej - jej organizacja, która ma tworzyć warunki zarówno do nauki, jak i kontaktów towarzyskich oraz biznesowych (Lefever, Bashir 2011)

\section{Pozostałe zasady zrównoważonego rozwoju}

Spośród wymienionych na wstępie zasad zrównoważonego rozwoju trzy dotyczą kwestii etyki i moralności uczestników ekologicznie zrównoważonej przestrzeni kampusu. Uczelnia wyższa jest szczególnie predysponowana do upowszechniania zasad etycznych, w tym przede wszystkim uczciwości i sprawiedliwości. Obie one stanowią kwintesencję etyki, która „wyznacza obowiązki moralne i wartości moralne. (...) Tak normatywnie pojęta etyka ma charakter teoretyczny i bezosobowy. Nie wyraża niczyich prywatnych poglądów, (...) mówi wprost, co jest dobre, a co złe, co stanowi przedmiot naszych powinności, a co jest przedmiotem zakazu” (Brandt 1996: XIII)

Każdy student inaugurujący studia składa ślubowanie, a także każdy promowany doktor składa przysięgę, w której zobowiązuje się przestrzegać etyki, dociekać prawdy, postępować moralnie itd. Jak pisze Brandt, przekonania są zawsze czyimiś przekonaniami, a moralność jest zawsze wytworem konkretnych jednostek lub grup. Etyka natomiast jest niezależna od czyichkolwiek opinii czy poglądów na temat norm i wartości moralnych. Etyka różni się od moralności tym, że ma obowiązywać „powszechnie i niezmiennie, niezależnie od tego, czy się jej przestrzega, czy nie” (Brandt 1996: XIV).

Teoria edukacji społecznej głosi, że celem edukacji moralnej jest dostarczenie brakujących motywów: pragnienie bezinteresownego czynienia tego, co słuszne, dla niego samego, i nieczynienia tego, co niesłuszne. Środkiem prowadzącym do tego jest aprobata lub dezaprobata, początkowo rodziców, później nauczycieli i innej władzy.

„Gdy dojrzewają możliwości rozumienia i ludzie stają się świadomi miejsca, jakie zajmują w społeczeństwie, oraz gdy są w stanie uchwycić punkt widzenia innych, zaczynają doceniać wzajemne korzyści z ustalenia uczciwych zasad współpracy. (...) Nieodzowną cechą społeczeństwa sprawiedliwego jest to, by wszyscy, kierując się wspólnie przyjętymi zasadami wzajemności, liczyli się z innymi” (Rawls 1994: 624-625).

Jak widać, w procesie edukacji moralnej uczelnia zajmuje poczesne miejsce, wspomagając proces kształtowania właściwych postaw u jednostek już rozwiniętych, ale jeszcze nie do końca ukształtowanych. Kampus zaś jest miejscem, gdzie proces ten się dokonuje. Nie przekazujemy wyłącznie wiedzy jako takiej (ekonomicznej, technicznej, medycznej itp.), lecz wiążemy ją z zasadami etycznymi. Nie chodzi też wyłącznie o zasady ściśle związane z daną nauką, takie jak np. społeczna odpowiedzialność biznesu czy przysięga Hipokratesa, lecz o wszystkie zasady etyczne obowiązujące w danym społeczeństwie, powszechnie i niezmiennie. Nauczyciele przekazują je młodzieży nie tylko słownie, ale przede wszystkim poprzez własne zachowania, którymi udowodniają zrozumienie i akceptację tych zasad.

Wśród tych trzech zasad zrównoważonego rozwoju nie jest wcale mało istotna kwestia oszczędzania zasobów i zaśmiecania naszej planety, gdyż chodzi w niej nie tylko o bieżące utrzymanie porządku, lecz także o zasadę sprawiedliwości międzypokoleniowej, zgodnie z którą powinniśmy przekazać naszym następcom Ziemię, a więc każde jej miejsce, w stanie nie gorszym, niż gdy otrzymaliśmy ją od naszych przodków.

Te trzy zasady etyczno-moralne są ściśle związane z pierwszą, czyli budową środowiska uczelni jak najbardziej zbliżonego do ekosystemu. Jest ona bowiem także zgodna z zasadą etyki i powinna być elementem moralności każdej jednostki oraz grupy społecznej, a w szczególności wykształconych elit.

\section{Kierunki zmian kampusów w badaniach SGH}

potrzebie dostosowania kampusu SGH do nowych oczekiwań jego użytkowników dyskutuje się od 10 lat (Bryx 2010). Z raportu z 2017 r. wynika, że wśród badanych kampusów europejskich najważniejszą tendencją jest dążenie do innowacji przez kształtowanie przestrzeni wewnętrznych i zewnętrznych w kierunku osiągnięci kampusu zrównoważonego, dającego satysfakcję młodzieży uczącej się oraz kadrze nauczającej, włączonego w tkankę miejską.

Jak twierdzi się na Uniwersytecie Technologicznym w Eindhoven, innowacja zaczyna się od ludzi, nie od technologiii. Od tych, którzy są pełni pasji i ciekawości, profesjonalni i otwarci. Oni ożywiają marzenia i pomysły. Są szczególnie ważn dla TU/e. To dzięki nim uniwersytet staje się miejscem, w którym pojawiają się innowacje. Tym pasjonatom trzeba stworzyć warunki do wizjonerskiej pracy. Tym samym wszelkie przebudowy, zmiany, przekształcenia przestrzeni akademickie zmierzają w kierunku umożliwienia tego dialogu grupy pasjonatów, ich twórczej wspólnej aktywności i włączenia w ten proces osób z zewnątrz uczelni.

Te zmiany mają na celu wprowadzenie komfortowych warunków w relacje nauczyciel-uczeń czy mistrz-uczeń, w których mistrz może być nie tylko akademikiem, lecz także przedstawicielem biznesu czy twórczym studentem. Zasada zadawania pytań i poszukiwania na nie logicznych odpowiedzi - o co tak zabiegał Platon - jest wciąż podstawą nauki, niezależnie od dokonanych zmian technicznych. Odpowiedzi na te wyzwania szuka się często w małych, interdyscyplinarnych, synergicznych grupach, którym uczelnia stwarza warunki do komfortowej pracy. Duże sale wykładowe stały się zabytkiem - i w przenośni, i często dosłownie. Natomiast wszędzie poszukuje się 
pomieszczeń niedużych do pracy grupowej oraz powierzchni wspólnych, swobodnie reorganizowanych na potrzeby chwili, np. dających możliwość stworzenia warunków swobodnej rozmowy po przypadkowym spotkaniu.

Poza potrzebami związanymi z kształceniem coraz większą rolę odgrywa jednak kompleksowość usługi bytowej, szczególnie dla osób mieszkających w przestrzeni kampusu. Sklepy spożywcze, fryzjer, sklepy z elektroniką, przedszkole to już raczej codzienność, obok najważniejszej - usługi dydaktycznej. Trzeba przyznać, że modyfikacja kampusu SGH jest wciąż na początku tej drogi. Niedobór przestrzen ogranicza możliwości. Poza filiami dwóch banków, partnerów uczelni, klub profesorski zmieniono $\mathrm{w}$ restaurację dostępną także dla osób z zewnątrz, rozbudowano księgarnię, adaptując jedną z szatni. Natomiast pomysł przywrócenia przedszkola, które funkcjonowało w latach 60., wciąż natrafia na bariery biurokratyczne, podobnie jak idea show-room pokazującego najnowsze osiągnięcia technologiczne.

Kolejną cechą badanych kampusów jest kreowanie wielu różnych przestrzeni wspólnych; miejsc, w których można „na siebie wpaść”, usiąść, położyć się, zwisać i omawiać intrygujące zagadnienia. Są to zarówno duże przestrzenie otwarte, jak i małe przestrzenie izolowane. Chodzi przy tym o odgrodzenie od hałasu, od ludzi pracujących nad innymi problemami, nie zaś o pozbawienie kontroli nad zachowaniem młodzieży. $Z$ tego powodu większość małych przestrzeni o charakterze zamkniętym jest wydzielona ścianą szklaną (fot. 12), przez którą widać, czy miejsce jest wolne, dostępne dla innych, czy też zajęte i w jaki sposób używane. Na większości uczeln najczęściej sale takie można rezerwować przez Internet, na innych - po prostu zająć, jeśli są dostępne. Podobnie w akademikach, zlokalizowanych na kampusie, takimi specjalnymi przestrzeniami ułatwiającymi kontakty i relacje międzyludzkie są kuchnie, przechowalnie (przedszkola) dla dzieci, pokoje do wspólnych działań, pracownie wyposażone w podstawowe narzędzia itp.

Ponadto w przypadku budynków rozrzuconych po dużym terenie podejmuje się próby ich łączenia w jeden kompleks systemem łączników - jest to konieczne na kompaktowym kampusie SGH. Inną metodą w przypadku rozległych kampusów jest tworzenie strefy centralnej (np. TU/e), gdzie mogą się spotkać i pracować razem studenci wszystkich wydziałów. Jest to też sfera funkcjonowania władz akademickich i administracji uniwersyteckiej.

Uczelnie ekonomiczne nie odbiegają potrzebami swoich studentów i kadry akademickiej od tego, czego potrzebują i co wdrażają inne uniwersytety. Wspólne przestrzenie, coworking, inkubatory i akceleratory biznesu itd. są tak samo oczekiwane. Różnice pomiędzy uczelniami w zapotrzebowaniu na przestrzeń wynikają z programów kształcenia i wielkości uczelni. Na uczelniach ekonomicznych jest zatem zdecydowanie mniejsze zapotrzebowanie na laboratoria, a ściślej biorąc, pojawia się zapotrzebowanie na innego typu laboratoria/pracownie niż na uczelniach technicznych. Pozostałe rodzaje przestrzeni są jednak równie pożądane.

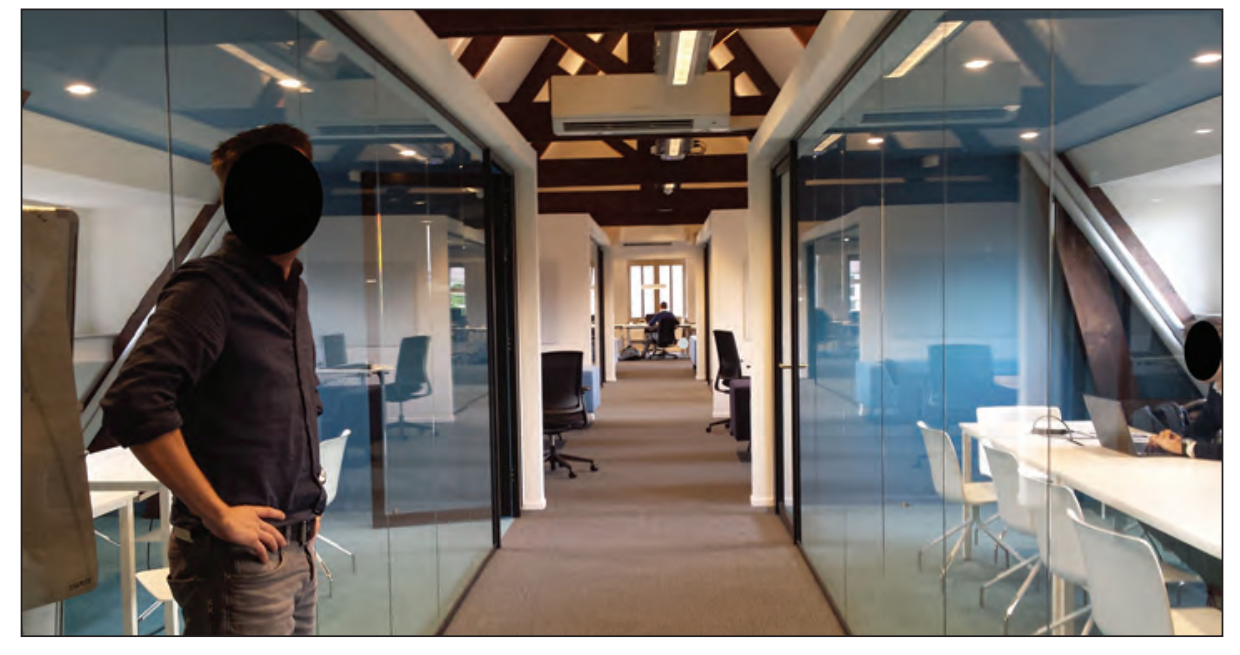

Fot. 12. Małe przestrzenie zamknięte w JADS (fot. M. Bryx)

Photo 12. Small closed spaces on the JADS campus (photo by M. Bryx)

Dla promocji innowacyjnych postaw niezbędne są przestrzenie wspólnej pracy o określonych walorach. Innowacyjne rozwiązanie jest wynikiem pracy zespołowej, a ona potrzebuje swojej własnej przestrzeni, która może być zlokalizowana w dowolnym miejscu - w ogrodach, piwnicach czy na strychach. Ważne jest, aby były łatwo dostępne i stały się miejscem spotkań różnorodnych osób, kreując efekt synergii ich działań.

Synergicznemu działaniu pojawiających się tam osób ma sprzyjać standard wykończenia i wyposażenia tych miejsc, umożliwiający swobodę zachowania, która jest niezbędna do nieskrępowanego myślenia. Ważne, by sprzyjał dialogowi, będącemu podstawą pracy wspólnej. Bez niej nie ma bowiem możliwości uzyskania efektu synergii, niezbędnego przy tworzeniu innowacji. Jak twierdzą zainteresowani, dobrze jest, jeśli w tej przestrzeni są nie tylko odpowiednie meble, lecz także „dobra kawa i kuchnia”.

Współpraca z biznesem w badanych kampusach przejawia się przede wszystkim w obecności (możliwie trwałej) firm zainteresowanych współpracą z uczelnią w przestrzeni kampusu. Przebywając stale na kampusie, zawierają trwałe związki z przedstawicielami nauki i studentami, stają się partnerami. Taka grupa tworzy kręgosłup współpracy, chociaż jej struktura ulega zmianie, kiedy pojawia się nowy problem do rozwiązania. Przykładowo, w JADS zlokalizowanych było 60 przedstawicieli przedsiębiorstw wobec około 300 studentów. Satysfakcja studentów i pracowników ze zwiększonej aktywności i kreatywności jest podstawą dalszych, konkretnych osiągnięć. Należy do nich rosnąca liczba współpracujących z uniwersytetami przed- 
siębiorstw, uzyskiwanych patentów i publikowanych artykułów naukowych, nowe organizacje biznesowe w postaci start-upów i spin-offów. Wszystko to przekłada się na rosnący prestiż uczelni i ich pozycję w europejskim obszarze nauki. Buduje także lub wzmacnia prestiż danej miejscowości i kraju, a także ma konkretne finansowe odniesienia, umożliwiające dalszy rozwój uczelni. Niestety, w SGH ze względu na niedobór powierzchni na terenie kampusu inkubator biznesu zlokalizowany jest w budynku poza nim. Wzmaga to dyskusję nad konieczną modernizacją kampusu.

Ogólnie oczekuje się, że zrównoważony kampus wyzwoli kreatywność pracowników i studentów oraz zachęci ich do etycznej współpracy z biznesem, w wyniku czego uczelnia stanie się dostarczycielem nowych patentów i rozwiązań technologicznych. Takiemu celowi powinny też przyświecać zmiany na kampusie SGH.

\section{Przyszłość kampusu SGH}

SGH jest otwarta na konieczne zmiany. Dostrzega swoje potrzeby i pragnie je zaspokoić. Od 2010 r., kiedy przeprowadzono pierwsze ankiety wśród studentów, odbyły się 3 konkursy na zagospodarowanie przestrzeni, warsztaty design thinking itp. Uczelnia nadal zbiera opinie i wnioski na temat tego, co jest potrzebne i co jest możliwe do zmiany w przestrzeni kampusu, w tym także od studentów z zagranicy (np. ankieta na Summer University Warsaw - lipiec 2017 r.).

Wspomniane badania dowiodły, iż tradycyjne wartości studiowania nie uległy zmianie, lecz zmieniły się częściowo techniki nauczania. Przykładowo, uznaną wartością wśród studentów i pracowników jest czytelnia SGH, w której zachowuje się ciszę, pozwalająca skoncentrować się na czytaniu i interpretowaniu czytanego tekstu. Niezależnie od tego studenci oczekują możliwości pracy w grupach, więc przestrzenie temu służące, wciąż niewystarczające, zostały jednak wygospodarowane.

Wiele lat temu władze SGH popełniły błąd, przekazując do gminy obiekty mieszkalne zlokalizowane na kampusie. W rezultacie $\mathrm{w}$ następnych latach, po prywatyzacji tych zasobów, na kampusie pojawiła się grupa osób niezainteresowana współpracą ze środowiskiem akademickim, z którym zajmuje wspólną przestrzeń. Co gorsza, pozbawiwszy się tych obiektów, SGH utraciła możliwość stałej obecności studentów na kampusie. Próba wybudowania od podstaw akademika dla studentów z typowymi udogodnieniami (sklep spożywczy, poczta, kafeteria, fryzjer, kuchnia, siłownia itd.) jest dużym wyzwaniem dla uczelni kompaktowej. Podobnie bez rozbudowy kampusu trudno jest wygospodarować wspólne przestrzenie coworkingowe, inkubatory i akceleratory biznesu itd.

$\mathrm{Z}$ dorobku przeprowadzonych dotychczas prac najciekawszy wydaje się projekt łączenia nowych potrzeb przy uwypukleniu historycznych walorów kampusu poprzez włączenie nowych funkcji zlokalizowanych w nowych przestrzeniach użytkowych do tkanki miejskiej (fot. 13). Projekt wykonali młodzi absolwenci Wydziału Architek- tury PW: Paweł Kubacz, Tomasz Trzupek, Paweł Wołejsza. Wykorzystano idealną lokalizację SGH na stacji metra, aby miejsce przesiadkowe uczynić nowoczesnym placem miejskim i niejako wymusić możliwość spotkań (fot. 14).

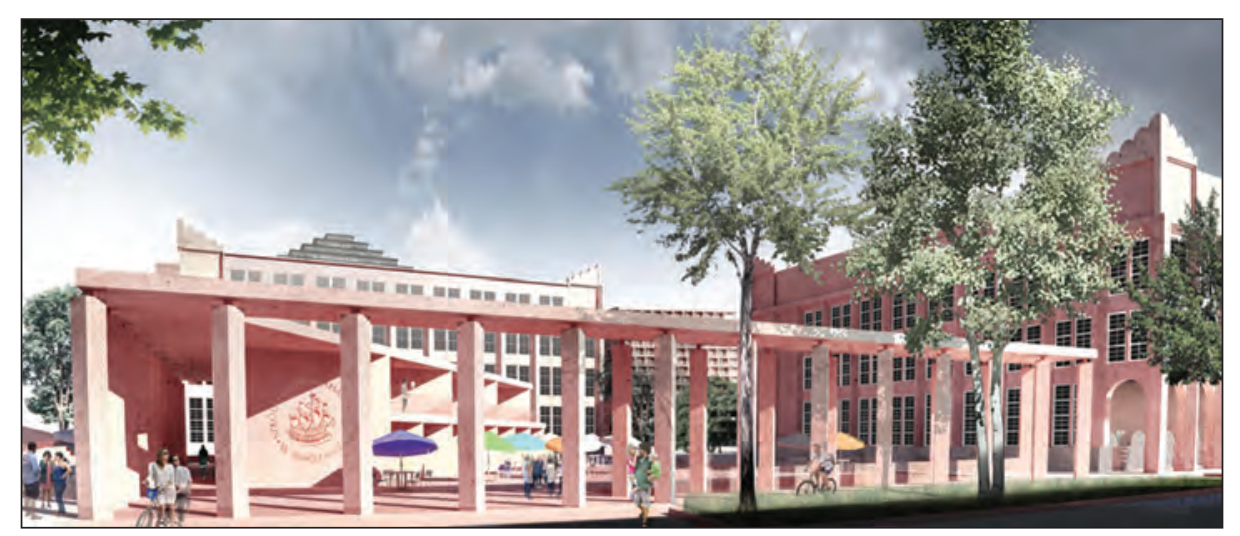

Fot. 13. Koncepcja nowego budynku na tle historycznego kampusu

Photo 13. Concept of a new building against the background of the historic campus Źródto: Archiwum SGH. / Source: SGH Archives.

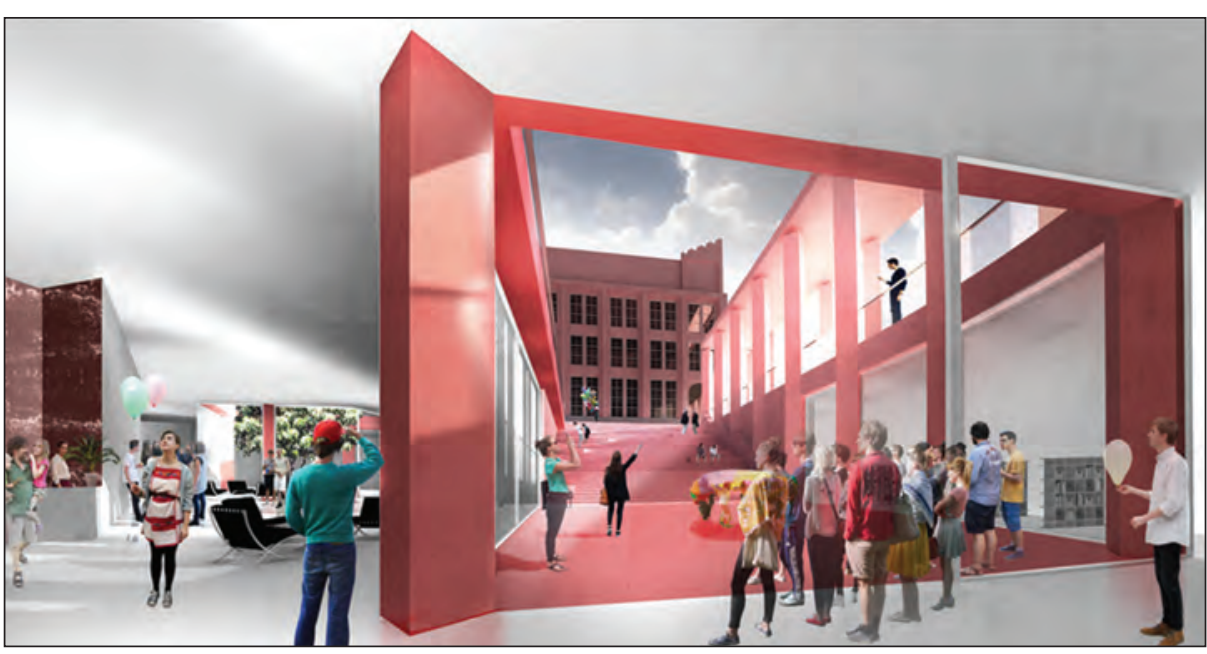

Fot. 14. Przebudowane wyjście ze stacji metra poprzez nowy budynek SGH Photo 14. Reconstructed exit from the underground station, through the new SGH building Źródto: Archiwum SGH. / Source: SGH Archives. 
Wydaje się, że wybudowanie dwóch niedużych gmachów oskrzydlających plac przed uczelnią, stwarzając tym samym nowe, otwarte i zamknięte przestrzenie dokładnie wzdłuż przebudowanego wejścia do metra, zbliżyłoby społeczność SGH nie tylko do najmniej odległych sąsiadów, ale przede wszystkim do innych uczelni, zwłaszcza PW i UW.

Ostatecznie jednak podjęto decyzję o budowie ekologicznego obiektu na działce przy ul. Batorego, który spełni te oczekiwania w ograniczonym zakresie.

\section{Podsumowanie}

Podsumowując, można stwierdzić, że na większości uczelni pojawiły się tendencje do głębszego wiązania przestrzeni (wewnętrznych i zewnętrznych) z naturą oraz tkanką miejską, także poprzez przenoszenie funkcji miejskich na teren uczelni. Srodowisko przyrodnicze było dostępne w przestrzeniach uniwersytetów, jednak w ostatnich latach zrobiono wiele, aby wszyscy użytkownicy kampusów dogłębnie uświadomil siebie jego znaczenie w naszym życiu, w prowadzeniu zajęć dydaktycznych i badań oraz propagowali tę wiedzę, te zachowania i postawy.

Podobnie upowszechnianie zasady etyki, postaw moralnych, wartości - to wszystko tkwi w istocie uczelni od starożytności. Jednak wraz z upowszechnianiem się populizmu i innych negatywnych zjawisk społecznych (autorytaryzm, brak poczucia odpowiedzialności) trzeba ugruntowywać wśród kształconych elit zasady etyczne wiodące nas do życia w zrównoważonym świecie. Nie wydaje się, aby można było to osiągnąć bez poczucia wspólnoty, obcowania studentów i profesorów, czego nie zapewni praca zdalna online.

\section{Literatura}

Brandt R., 1996, Etyka. Zagadnienia etyki normatywnej i metaetyki, PWN, Warszawa. Bryx M. (red.), 2010, Nowe myślenie o przestrzeniach uniwersytetu: rewitalizacja Szkoty Gtownej Handlowej w Warszawie, Okrągły Stół INTA/KNoP SGH, OW SGH, Warszawa.

Bryx M. (red.), 2017, Z tradycjq w nowoczesnośc. Raport z badañ pn.: Innowacyjne przestrzenie warunki dla twórczej pracy w nauce i biznesie, materiał powielony, SGH, Warszawa.

Bryx M., Przestrzenie kampusu, Tallin, 27 maja 2011, https://inta-aivn.org/images/stories/inta-aivn/activities/exchange/roundtables/Tallinn/Tallin_Marek_Bryx.pdf (dostęp: 8.11.2020). Dembiński B., 2010, Późny Platon i Stara Akademia, Wyd. Marek Derewiecki, Kęty.

Gawerski A., 2007, Præedmowa, [w:] B. Miklaszewski, Pamiętniki, OW SGH, Warszawa.

Górski F., 2010, Ankieta zagospodarowania kampusu SGH, [w:] M. Bryx (red.), Nowe myślenie o przestrzeniach uniwersytetu: Rewitalizacja Szkoty Gtownej Handlowej w Warszawie, Okragły Stół INTA/KNoP SGH, OW SGH, Warszawa.
Lefever R., Bashir H., 2011, Student Engagement Final Report: Exploring Student Understandings of Belonging on Campus, Higher Education Academy and University of Bradford, Bradford, UK.

Leśniakowska M., 1998, Architekt Jan Koszczyc Witkiewicz (1881-1958) i budowanie w jego czasach, Instytut Sztuki Polskiej Akademii Nauk, Warszawa.

Miklaszewski B., 2007, Pamiętniki, OW SGH, Warszawa

Morawski W. (red.), 2015, Historia zabytkowego kampusu Szkoty Gtównej Handlowej w Warszawie, OW SGH, Warszawa.

Rawls J., 1994, Teoria sprawiedliwości, PWN, Warszawa.

Szelągowska A., Bryx M. (red), 2015, Eco-innovation in cities, CeDeWu, sp. z o.o. e-book, Warszawa.

Trzcińska B., 2015, Kampus Szkoty Gtównej Handlowej w Warszawie - architektura šwiatta, OW SGH, Warszawa.

Witkiewicz-Koszczyc J., 1933, Budowa Gmachu Bibliotecznego Wyæssej Szkoty Handlowej w Warszawie, WSH, Warszawa.

Marek Bryx (ORCID: 0000-0003-0768-4786)

Szkota Gtowna Handlowa w Warszawie

Katedra Miasta Innowacyjnego

Al. Niepodlegtości 162

02-554 Wars:awa

mbryx@sgh.waw.pl 
